\title{
Trends on the relationship between board size and financial and reputational corporate performance The Colombian case
}

\author{
Luis Antonio Orozco and Jose Vargas \\ School of Management, Universidad Externado de Colombia, \\ Bogota, Colombia, and \\ Raquel Galindo-Dorado \\ Accounting, Faculty of Economics and Business Sciences, \\ Autonomous University of Madrid, Madrid, Spain
}

\begin{abstract}
Purpose - The purpose of this paper is to investigate the relationship between board size (B-SIZE) and financial and reputational corporate performance in top companies ranked by the Business Monitor of Corporate Reputation - MERCO in Colombia.

Design/methodology/approach - This paper conducts correlations and cluster analysis in order to classify firms based on performance and control variables, using a sectional sample of 84 large companies in Colombia over the period 2008-2012.

Findings - This research founds that large boards are associated with high performance on corporate reputation, as stated by the resource dependence theory, and a low-financial performance, as predicted by the agency theory. However, the results indicate that there is no relation between financial and reputational performance.

Research limitations/implications - This research considered only large companies listed by MERCO. Therefore, the results can only be generalized for top firms in Colombia according to this list. However, results add empirical evidence to theoretical debate between B-SIZE and firm performance considering financial and reputational indicators.

Practical implications - According to the OECD manual of good corporate governance practices, the optimal B-SIZE has between five to nine core members. The board structure has a direct impact over the firm's financial and reputational performance and must be carefully analyzed by shareholders to balance the size according to expected results and firm's features like family ownership, exportation activities and norms of stock markets.

Originality/value - This paper contributes to the existing literature on the relationship between B-SIZE and corporate performance with the evaluation of financial and reputational results for the case of an emerging economy. In Latin America, this analysis must go beyond OECD recommendations, and shall consider the context of an emerging country based on empirical evidence.
\end{abstract}

Keywords Corporate reputation, Organizational theory, Colombia, Financial performance, Board size

Paper type Research paper

\section{Introduction}

The relationship between the size of the board of directors and corporate performance is a fundamental issue in corporate governance (Cheng, 2008). There are two main opposite theoretical approaches to the relationship between board size (B-SIZE) and corporate performance. Agency theory, from an economic perspective, determines that fewer

(C) Luis Antonio Orozco, Jose Vargas and Raquel Galindo-Dorado. Published in the European Journal of Management and Business Economics. Published by Emerald Publishing Limited. This article is published under the Creative Commons Attribution (CC BY 4.0) licence. Anyone may reproduce, distribute, translate and create derivative works of this article (for both commercial and non-commercial purposes), subject to full attribution to the original publication and authors. The full terms of this licence may be seen at http://creativecommons.org/licences/by/4.0/legalcode 
EJMBE

27,2

184

board members improve monitoring, control and corporate financial performance (FP) (Jensen, 1993). On the other hand, Resource dependence theory, based on a more sociological approach, states that large boards improve advisory capacity, counseling, deliberation and external relations, and thus FP of firms (Pfeffer, 1972). However, research about B-SIZE and financial indicators has not produced conclusive results (Dalton et al., 1999; Cheng, 2008; Belkhir, 2009; Guest, 2009; Palaniappan, 2017; Yasser et al., 2017).

Corporate performance has incorporated new measures that go beyond financial indicators (Said et al., 2003), especially those within the scope of the Global Reporting Initiative (Skouloudis et al., 2010). Several studies have found that there is a positive relationship between B-SIZE and non-FP. This positive relationship has a substantial impact on the sustainability of the firm (Chaganti et al., 1985; Platt and Platt, 2012), including firm' environmental indicators (de Villiers et al., 2011) and its operational performance and social welfare (Kao and Kao, 2013). However, little progress has been made on assessing the relationship between B-SIZE and corporate reputation (Musteen et al., 2010).

The relationship between financial and reputational results tends to be positive as indicated in several studies using Fortune's information (Fuente and Quevedo, 2003; Hammond and Slocum, 1996). However, the study from Flanagan et al. (2011) about companies listed in Fortune's 2006 rank found that the relationship between reputation and financial indicators is not as strong as Brown and Perry (1994) reported in Fortune (1991), and the virtuous cycle between reputation and financial results is not as clear as Dunbar and Schwalbach (2000) found for the German firms. Also, to our knowledge, there are no empirical studies evaluating this relationship regarding the effect of B-SIZE. Then, the purpose of this research is to expand the knowledge on this relationship to contribute to the theoretical development of corporate governance using empirical evidence from an emerging economy such as Colombia.

The development of corporate governance in Colombia is still incipient. Based on the OCDE and the Andean Development Corporation guidelines, the corporate governance Country Code was introduced in 2007. Although the adoption of these standards is not legally mandatory, different entities such as the Financial Superintendence and the Superintendence of Corporations, together with the Colombian Confederation of Chambers of Commerce - Confecamaras[1], have been encouraging companies to implement corporate governance practices. Additionally, contingency factors and institutional lobbying exerted by the stock market, as well as the internationalization process and growth of family businesses (FBs), among other variables, have led companies to adopt governance structures using the Colombia Country Code guidelines. However, best-practice guidelines on corporate governance do not support their recommendations on empirical evidence; thus, the relationship between B-SIZE and corporate performance is just a normative recommendation. In fact, the empirical research upon corporate governance in Latin America is limited and focused on FP without considering B-SIZE as the main variable to achieve results (Garay et al., 2006; Lefort and Urzúa, 2008; Castro et al., 2009; Fernández et al., 2015).

This paper contributes to fill a gap in the literature, evaluating the association between B-SIZE and financial and reputational performance, using a sample of the 84 largest companies in Colombia as listed by MERCO over the term 2008-2012. Moreover, it will provide additional insight on both the agency theory and the resource dependence theory on B-SIZE, corporate performance, and best practices in corporate governance.

This paper is structured as follows: the first section develops the theoretical debate, the second presents the literature review and research hypotheses. The third part presents the methodology and results. The paper ends with conclusions and issues to be considered for future research. 


\section{Theoretical approach}

Agency theory (Jensen and Meckling, 1996) states that small boards have more managerial control. Jensen (1993, p. 865) stated that "keeping boards small can help improve their performance", and stressed that boards with more than seven members are prone to inefficient operations, lack of commitment, moral hazard problems, and greater control by the CEO. Resource dependency theory (Pfeffer and Salancik, 1978) has found evidence that an increase in B-SIZE provides access to external relationships which brings further information and access to financial and inter-organizational coordination (Pfeffer, 1972), especially upon interlocking directorates (Mizruchi, 2004). Large boards can improve the richness of perspectives, access to information and resources, and the quality of opinions and deliberation upon decision making, as well as the strategic spectrum of the company (Belkhir, 2009; de Villiers et al., 2011). However, as stated by Pfeffer (1972, p. 226) "B-SIZE and composition are not random or independent factors, but are, rather, rational organizational responses to the conditions of the external endowment."

Theoretical proposals integrating agency theory and resource dependence theory have been developed to understand the relationship between board of directors and corporate performance. The integrative model proposed by Zahra and Pearce (1989) highlights the importance of contingency factors proposed by agency theory, such as ownership concentration and stock markets, and type of business and external relationships as resource dependence theory proposed. Hillman and Dalziel's (2003) integrative model suggests that human capital (experience, expertise and reputation) and social capital (networks with other organizations and the environment) of the boards affect monitoring and advisory activities, while incentives to directors moderate the relationship between board characteristics and firm performance. However, these integrative models do not consider the possible dichotomy between financial and reputational performance, as financial results are more associated to agency theory while reputation is more related to resource dependence theory.

Regarding the relationship between financial and reputational performance, Quevedo et al. (2005) proposed a cyclical model based on organizational legitimacy defined by the general perception that organizations comply with a number of legal rules to produce, exchange goods and services and perform property activities, as suggested by the economic model, as well as a transparency upon information and results delivered which favor the expectations among stakeholders that are directly or indirectly involved with the organization as documented by the sociological approach. The model understands the board "as intermediary from the contractual relations that take place in the company, which exerts as a mediator to safeguard the legitimacy" (Quevedo et al., 2005, p. 89). The nexus of explicit and implicit contracts creates a commitment upon directors to generate reputation and FP for the organization, which in turn fosters trust and reduces transaction costs by increasing organizational efficiency and stakeholder's satisfaction (Quevedo et al., 2005).

According to integrative models, there are many contingencies that can affect the relationship between B-SIZE and corporate performance. One of the key variables described in agency theory is the concentration of property in specific families (Carney, 2005; Delgado-García et al., 2010). Incentives, such as family ties within the firm may increase the monitoring and advisory efforts to outperform corporate results (Hillman and Dalziel, 2003). Given the nature of family-controlled firms, boards tend to be small (Neubauer and Lank, 1998; Corbetta and Salvato, 2004; Casillas and Vásquez, 2005). However, large companies require large boards, with people from diverse backgrounds and experiences to improve decision making (Zahra and Pearce, 1989). Similarly, commitments with stock markets and the internationalization of activities of companies could also incentivize boards toward achieving better financial and reputational performance. These contingencies require both control and advisory skills that have an impact on the size of the boards.
Reputational corporate performance 
EJMBE

27,2

186

On the one hand, according to legislation and requirements on information transparency, stock market listed companies may have smaller boards. This is supported by empirical evidence and as suggested by the agency theory (Yermack, 1996; Tonello, 2010). On the other hand, activities like exportation increases risks, thus companies need greater number of members in their board as suggested by the resource dependence theory in order to improve their counseling capacity and inter-organizational relationships across national borders (Schwaiger, 2004; Calabrò and Mussolino, 2011; Barroso et al., 2011). These contingencies will be the basis for empirical research in this paper.

\section{Literature review and research hypotheses}

According to the previous section, B-SIZE has implications for the achievement of corporate performance, including financial and non-financial results like corporate reputation. The following literature review presents the main theoretical approaches developed to explain the relationship between B-SIZE and corporate performance.

\section{B-SIZE and FP}

FP reflects the ability to create economic value. The most commonly used indicators in the literature are the firm's value (Tobin's $Q$ ), return on equity (ROE), return on assets (ROA), and net sales, which represent the ability of corporations to use resources efficiently and their market share. Several empirical studies found a negative relationship between B-SIZE and financial outcomes, in developed countries such as the USA (Yermack, 1996; Lehn et al., 2009), Finland (Eisenberg et al., 1998), the UK, France, Holland, and Italy (Conyon and Peck, 1998), Denmark (Bennedsen et al., 2008), and in emerging Asian economies such as Singapore and Malaysia (Mak and Kusnadi, 2005), Thailand (Yammeesri and Herath, 2010) and India (Chatterjee, 2011; Kumar and Singh, 2013). These findings support the explanations from agency theory (Harris and Raviv, 2006), about highlighting the importance of small boards to monitoring and controlling corporate management.

However, the results obtained in the analysis of data from the Investor Responsibility Research Center -IRRC- show a negative relationship between B-SIZE and Tobin's $Q$ and ROA (Cheng, 2008). Studies like Belkhir's (2009) for the US banks have found that an increase in B-SIZE delivers better FP. Also, Guest (2009) found for the UK listed firms that larger boards have a negative impact on profitability. This relationship was also found in Asian economies like Japan (Xie and Fukumoto, 2013; Bonn et al., 2004), India (Jackling and Johl, 2009; Sarpal and Singh, 2013; Palaniappan, 2017), Malaysia (Shukeri et al., 2012), Thailand (Glaewketgarn, 2013), China (Liang et al., 2013) and Pakistan (Yasser et al., 2017), as well as in emerging economies in Africa like the case for banks in Kenya (Chepkosgei, 2013), and firms in Nigeria (Ehikioya, 2009; Uadiale, 2010; Ugwoke et al., 2013).

According to Pfeffer (1972), B-SIZE depends on the conditions of the environment. Specifically, the conditions of economic volatility and uncertainty experienced in developing countries may lead to boards with a greater number of members to establish more and better relationships with other organizations and the environment, and to provide valuable resources for better FP. In Latin America, the case of Chile showed a positive relationship between B-SIZE and Tobin's $Q$ in a sample of 160 firms (Lefort and Urzúa, 2008). Therefore, it is possible to think that in emerging economies larger boards are needed to face the challenges of economic value creation. Based on this this paper propose that:

H1. In Colombia, B-SIZE is associated to FP.

\section{Size of the board and corporate reputation}

Reputation is a collective perception built in a process of social construction and validation. Corporate reputation refers to a common opinion about past actions and future expectations 
that people have of an organization, which generates esteem and prestige when compared to other organizations (Fombrun, 1996). The configuration and structure of boards is one of the key corporate reputation factors (Gabbioneta et al., 2007; Iwu-Egwuonwu, 2011). Including more members brings greater opportunities to manage corporate reputation and to establish relationships with external environments (Hillman et al., 2000; Musteen et al., 2010). Large boards tend to have directors with diverse backgrounds and relationships that enable organizations to project their image (Hillman et al., 2000). Likewise, directors have their own reputation that helps extend a positive esteem of the corporation (Zahra and Pearce, 1989; de Villiers et al., 2011).

Chaganti et al. (1985) found that successful companies had larger boards than those firms that did not survive. This result is confirmed by Platt and Platt (2012) in a comparative study between bankrupt companies and those remaining afloat according to RiskMetrics database. B-SIZE is positively associated to non-FP in hospitals in Taiwan (Kao and Kao, 2013) and environmental performance in the US companies (de Villiers $e t$ al., 2011). Other studies show also that a B-SIZE increase with independent directors is related to additional reputational benefits for the organization (Hillman et al., 2000; Raheja, 2005).

Finally, Musteen et al. (2010) conducted a study of Fortune listed corporations in which they show that companies with large boards and a high presence of external directors have better reputation than companies with small and homogeneous boards. In fact, "B-SIZE has been widely used as a metric by governance rating agencies in evaluating corporate boards [...], with firms that have relatively smaller boards often being viewed unfavorably by such agencies. [...] In other words, having more, rather than fewer, directors, firms ensure that they are in compliance with institutional expectations" (Musteen et al., 2010, p. 502).

According to the evidence above and the sample used, this paper proposes that:

H2. In Colombia, B-SIZE is associated to corporate reputation.

\section{Corporate performance: the relationship between financial and reputational indicators}

During the process, whereby a corporation increases its contribution to the wealth of nations through their financial results (new jobs, taxes, products that meets needs, sustainability), an image emerges, and its name is associated with what is considered good and legitimate, thus creating corporate reputation (Fombrun and Shanley, 1990; Deephouse, 1997; Roberts and Dowling, 2002). Firms can emerge with the reputation of the entrepreneur, as William Durant and Steve Jobs demonstrated in the case of Chevrolet and Pixar respectively. However, firms need to sustain their FP to gain recognition in the long term. Then, the creation of tradition and credibility among generations, which is called sustainability (Rivera, 2012), is more valuable to stakeholders than financial analysis (Walsh and Wiedmann, 2004), and this credibility implies the improvement of financial indicators as a study on corporations in China revealed (Zhang and Rezaee, 2009).

Reputation becomes a competitive advantage and an asset that allows corporations to invest, expand, and increase their financial results in a virtuous circle of recognition and economic value creation (Roberts and Dowling, 2002; Quevedo et al., 2005; Iwu-Egwuonwu, 2011) leading to customer loyalty (Eberl and Schwaiger, 2005). Theoretical propositions in the frame of marketing research highlights the importance of corporate reputation to steer better FP due to the social performance achieved in the light of stakeholder's satisfaction (Neville et al., 2005). A review of literature performed by Fuente and Quevedo (2003, p. 176) "shows empirical support for both directions of the relationship between corporate reputation and FP: corporate reputation influences FP and vice versa." With this evidence, Quevedo et al. (2005) proposed a cyclical model for financial and reputational corporate 
EJMBE

27,2

performance to explain how economic value creation implies duties for managers to perform socially trying to meet the several interests of stakeholders to gain legitimacy.

However, Walsh and Wiedmann (2004, p. 310) proposed that "corporate reputation is a multi-dimensional construct that has an impact on stakeholder behavior and that it can differ across countries." There are national cases that do not reveal a relationship between reputational and FP, like Denmark (Rose and Thomsen, 2004); Australia (Inglis et al., 2006) and Turkey (Caliskan et al., 2011). For German firms, Dunbar and Schwalbach (2000) found that prior FP has a positive impact on reputation. It has to be noted that reputation does not present the same impact in subsequent FP. Also, as Lee and Jungbae-Roh (2012) pointed out, the effect of corporate reputation on FP is contingent on firm characteristics.

Despite these findings, a special issue from the most renowned business magazine in Colombia, based on information from the Reputation Institute, stated that: "a point of growth in a company's reputation is correlated to one point increase upon profitability and just below one point in relationship to the financial assessment" (Dinero, 2013, p. 74). This assertion implies that better financial indicators lead to better corporate reputation. Then, in accordance with $H 1$ and H2, and in order to test Quevedo et al. (2005) proposal, this paper proposes that:

H3. In Colombia, FP is associated to corporate reputation.

\section{Methodology}

\section{Sample}

MERCO provides valuable information for empirical research in Ibero-America (Delgado-García et al., 2010)[2]. A sample of 84 large companies was obtained using the Colombian' MERCO ranking for the period 2008-2012. In 2007, the Country Code of corporate governance was launched and in 2008 Colombia was included as a potential member of the OECD, and then, good practices of corporate governance have been increasing with the support of Confecamaras, the Financial Superintendence and the Superintendence of Corporations in the period selected. These companies are the most representative corporations in Colombia and include FBs, multinational organizations, and Colombian traditional enterprises in several industries including manufacturing, services and trade.

\section{Method}

To test the hypotheses, we propose to use Spearman rank correlation and the $K$-mean cluster analysis approach. Spearman correlation measures the degree of association between two variables that are ordinal data. Cluster analysis allows the creation of groups of firms that share similar characteristics in a sectional sample and identify the trend of association of variables. Using this approach, the study can reveal if a group of firms with many or few members in the boards of directors also present high or low financial and reputation results. We used a $\chi^{2}$ and $F$-test for variable independence among clusters of firms, and cluster differences to ensure results reliability.

\section{Variables}

B-SIZE, the authors used the BPR Benchmark's database[3] to obtain the number of board members. According to B-SIZE classification used in empirical studies like Bennedsen et al. (2008), the authors classified the B-SIZE in three categories. Low (between 0 to 5 members) coded as 1; medium (boards with at least 7 members), coded as 2; and high: boards with more than 7 members, coded as 3 .

FP, the BPR Benchmark was used to obtain the ROE, ROA and the net sales average for the years covered by this study. The authors then conducted a factorial analysis among 
these three FP dimensions to create a variable synthesizing the creation of wealth in terms of access to markets and efficiency of the use of resources. The values of the factorial analysis are presented in Table I. The first 28 companies with the lowest factorial value were identified as 1 ; the following 28 firms as 2 , and the remaining 28 as 3 . This variable will be used in the cluster analysis.

Corporate reputation - CR, the MERCO ranking was used by the authors to calculate the average position on the scale of corporate reputation for each company over the term 2008-2012. As the first positions of the ranking were held by the most reputed companies, the order of the firms was inverted to ensure consistency with the order of the values (high, medium, or low). Subsequently, the first 28 companies with the lowest rank were identified as 1 , the next 28 as 2 and the remaining as 3 .

Control variables. FB, the authors used information from the Colombian Stock Exchange[4] and corporative web pages to identify ownership concentration. Firms controlled by a single family, namely, with over 50 percent shareholding ownership were given a value of 1 , while a value of 0 was given otherwise.

Export activities - Exp., export firms were given a value of 1 while a value of 0 was given to non-exporting firms. The BPR Benchmark was used to establish these values.

Colombian stock market - CSM, listed companies were given a value of 1 whereas non-listed companies were given a value of 0 . The authors used information from the Colombian Stock Exchange to establish these values.

\section{Results}

As reported in Table I, 38 boards have seven members, which account for 45 percent of the companies in the sample. Likewise, 87 percent of the firm's boards have between five and nine members, while in the USA most companies have 9-12 board members (Tonello, 2010). It is worth noting that 18 out of $21 \mathrm{FBs}$ of the sample presented in Table I have boards of 5-7. B-SIZE in companies with high Exp. range from 9 to 11 members, just as the companies listed in the Colombian Stock Exchange. This indicates that internationalization of activities and participation in stock markets are led by boards with a larger number of members. This result is confirmed by Herrera-Echeverri et al. (2015) who compiled a large sample of family firms in Colombia.

\section{The relationship between the size of the board and corporate performance}

According to the OECD, the optimal B-SIZE in Latin America ranges from five to nine core members (Garay et al., 2006), and empirical evidence in the region shows that the average B-SIZE is nine members (Castro et al., 2009). According to agency theory, smaller boards are expected to be formed to ensure control functions, while resource dependency theory

\begin{tabular}{|c|c|c|c|c|c|c|c|}
\hline B-SIZE & Firms & CR average & FP average & FB average & Exp. average & CSM average & \\
\hline 0 & 1 & 70.00 & 0.04 & 1.00 & 1.00 & 0.00 & \\
\hline 3 & 1 & 40.00 & 0.37 & 0.00 & 1.00 & 0.00 & \\
\hline 5 & 22 & 43.68 & -0.08 & 0.36 & 0.55 & 0.45 & \\
\hline 7 & 38 & 39.13 & -0.09 & 0.26 & 0.71 & 0.42 & \\
\hline 9 & 13 & 47.38 & -0.13 & 0.15 & 0.77 & 0.54 & \\
\hline 11 & 5 & 51.40 & -0.32 & 0.00 & 0.80 & 0.60 & \\
\hline 12 & 2 & 31.50 & 0.68 & 0.00 & 0.50 & 1.00 & \\
\hline 13 & 1 & 30.00 & 6.57 & 0.00 & 1.00 & 0.00 & \\
\hline 19 & 1 & 62.00 & 0.36 & 0.00 & 1.00 & 0.00 & Table I. \\
\hline Total & 84 & 42.69 & $1.19 \mathrm{E}-07$ & 0.25 & 0.69 & 0.45 & Frequencies \\
\hline
\end{tabular}

Reputational corporate performance 
EJMBE 27,2

190

maintains that large boards are aimed at promoting counseling functions (Hillman and Dalziel, 2003). Table I shows that average corporate reputation (CR) - until five board members - is lower than the average reputation of companies with nine members in their boards. Nevertheless, boards of 7 have a lower average reputation than both five and nine member boards. Moreover, the average FP is higher for boards of five than for nine-member boards. This could indicate that boards of five members tend, on average, to have a better FP than larger boards, and, on the other hand, the CR tends to be higher for nine member boards, which are possibly designed more to address counseling than control functions. These results are consistent with Musteen et al. (2010) findings which show that large boards are positively related to corporate reputation, and with Cheng's (2008) finding that small boards are positively related to FP.

As reported in Table II, there is no correlation between B-SIZE and CR-FP. Thus, performance could be independent from board structure. Likewise, there is no correlation between $\mathrm{CR}$ and $\mathrm{FP}$, indicating that both types of performance do not show a virtuous cycle as suggested by the integrative model and empirical evidence revealed in Fortune 500's study (Quevedo et al., 2005).

The integrative model (Quevedo et al., 2005) emphasizes the importance of firm's characteristics. It is important to highlight some of the relationships found in control variables (FB, Exp. and CSM). CR has a positive relationship with CSM and a negative relationship with FB. The Colombian sample indicates that companies with the best reputation are usually stock market listed firms rather than family-run businesses. FB has a significantly negative correlation with B-SIZE and CSM. In Colombia, the percentage of FB in CSM is low (Gómez-Betancourt et al., 2012). This indicates that FBs tend to have fewer members on their boards and less participation in the stock market. Finally, export companies are not included in the CSM. This is partly explained by the fact that such companies are listed in other international stock exchange markets. It is therefore possible to conclude that the most reputable companies are those listed in the stock market. Also, family-run firms are not generally listed in the stock market and do not perform Exp., as could be expected considering Herrera-Echeverri et al. (2015) findings. Finally, export companies are negatively correlated to those listed in the stock market, a fact which can be explained by the performance of multinational companies with high level of activity in foreign trade but that are not necessarily listed in the Colombian stock exchange market.

A cluster analysis was performed in order to test our research hypotheses, the results of which are presented in Table III. To this end, two groups were set up: the first was comprised by 47 companies and the second by 37, showing a proper separation of the sample. Cluster 1 included companies with larger boards. Cluster 1's CR centroid is greater than that of Cluster 2. Also, the FP centroid in Cluster 1 is smaller than the centroid in Cluster 2. This result indicates that firms with larger boards have better performance on CR and lower FP. To prove the reliability of this conclusion, Table IV presents an ANOVA analysis to assess whether there is a statistical difference between clusters means. The null

Table II.

Descriptive statistics and Spearman correlations

\begin{tabular}{lccccccccccc}
\hline & $n$ & Min. & Max. & Mean & SD & B-Size & CR & FP & Exp. & FB & CSM \\
\hline B-SIZE & 84 & 1.00 & 3.00 & 1.9643 & 0.75165 & 1 & 0.039 & 0.137 & 0.140 & $-0.267^{* *}$ & 0.107 \\
CR & 84 & 1.00 & 3.00 & 2.0000 & 0.82140 & & 1 & -0.018 & -0.000 & $-0.269^{* *}$ & $0.322^{*}$ \\
FP & 84 & 1.00 & 3.00 & 2.0000 & 0.82140 & & & 1 & 0.126 & 0.067 & -0.088 \\
Exp. & 84 & 0.00 & 1.00 & 0.6905 & 0.46507 & & & & 1 & 0.030 & $-0.323^{*}$ \\
FB & 84 & 0 & 1 & 0.25 & 0.436 & & & & & 1 & $-0.525^{*}$ \\
CSM & 84 & 0 & 1 & 0.45 & 0.501 & & & & & & 1
\end{tabular}

Notes: $* p=0.01 ; * * p=0.05$ 
hypothesis of the $F$-test is that the means are equal. This hypothesis is rejected for all three variables of interest (B-SIZE, CR and FP). Therefore, there are statistical differences between both groups. Thus, H1, which suggests that B-SIZE is associated to FP can be rejected, and $H 2$, wherein B-SIZE is associated to CR cannot be rejected.

We also used a $\chi^{2}$ test of independence to test $H 3$, which suggests that FP is related to $\mathrm{CR}$. Table V shows the $\chi^{2}$ test results, the null hypothesis of which is the independence between variables. Given that $p$-value significance is greater than 0.05 , the null hypothesis is not rejected. Therefore, it is possible to argue in line with the lack of correlation established in Table II, that FP and $\mathrm{CP}$ are statistically independent, so we reject $H 3$. Consequently, this finding does not support the virtuous cycle theoretical approach, as proposed by Quevedo et al. (2005) in the case of Colombian top companies.

\section{Conclusion and implications}

This research found that companies with large boards tend to show higher corporate reputation and lower FP than companies with smaller boards. The evidence presented in this research reveals that the association between financial and reputational performance is not found in the Colombian case. Furthermore, this research shows that firms with smaller boards tend to be listed in the stock market, assume less risk related to Exp. and deliver the highest financial results. In contrast, firms with large boards tend not to be listed in the

\begin{tabular}{llcc}
\hline & & Cluster & \\
& 1 & 2 & \\
B-SIZE & 2.30 & 1.54 & \\
CR & 2.40 & 1.49 & \\
FP & 1.72 & 2.35 & \\
FB & 0 & 0 & Table III. \\
CSM & 0 & 1 & Centroid of the \\
Exp. & 0.79 & 37 & Cluster $K$-means \\
$n$ & 47 & & \\
\hline
\end{tabular}

Reputational corporate performance

\begin{tabular}{|c|c|c|c|c|c|c|c|}
\hline & $\begin{array}{r}\text { Cluster } \\
\text { Quadratic media }\end{array}$ & $\mathrm{df}$ & $\begin{array}{l}\text { ANOVA } \\
\text { Error } \\
\text { Quadratic media }\end{array}$ & df & $F$ & Sig. & \\
\hline B-SIZE & 11.874 & 1 & 0.427 & 82 & 27.804 & 0.000 & \\
\hline $\mathrm{CR}$ & 17.438 & 1 & 0.470 & 82 & 37.080 & 0.000 & \\
\hline FP & 8.163 & 1 & 0.583 & 82 & 13.993 & 0.000 & \\
\hline FB & 0.075 & 1 & 0.191 & 82 & 0.395 & 0.532 & \\
\hline CSM & 1.337 & 1 & 0.237 & 82 & 5.632 & 0.020 & Table IV. \\
\hline Exp. & 0.999 & 1 & 0.207 & 82 & 4.832 & 0.031 & Anova and $F$-test \\
\hline
\end{tabular}

\begin{tabular}{lcccc}
\hline & Value & df & Sig. & \\
\hline Pearson's $\chi^{2}$ & 0.857 & 4 & 0.931 & \\
Likelihood ratio & 0.858 & 4 & 0.931 & Table V. \\
Linear-by-linear association & 0.026 & 1 & 0.871 & $\chi^{2}$ test \\
\hline
\end{tabular}


EJMBE

27,2

stock market, carry out Exp. and show higher reputational results. Finally, FBs do not tend to have large boards, are not listed in stock markets and are not at the top of reputed firms in Colombia.

With regards to the literature reviewed for this paper, large boards support synergies among financial and reputational performance, and are more appropriate for the endowments and conditions of an emerging economy. The case of Colombian top companies does not provide evidence of a virtuous cycle between financial and reputational performance. The results of Cluster 1 (47 firms) partially support the arguments of resource dependence theory, which hold that increasing the size of the board can improve the ability of firms to interact with their environment, acting as boundary spanners, thus leading to a better corporate reputation. Furthermore, the results obtained for Cluster 2 (37 companies) partially support the statement from agency theory that a smaller B-SIZE allows an improvement on management, monitoring and control functions, and thus allow better financial results.

The main theoretical implication of this research is that contingency approach, which integrates resource dependence and agency theory (Zahra and Pearce, 1989; Hillman and Dalziel, 2003), need to include not only FP, but also corporate reputation as a result of board structure to introduce the discussion about the virtuous cycle between financial and reputational corporate performance (Quevedo et al., 2005).

For practical implications, shareholders must consider that B-SIZE is correlated to different performance results and variables of the company. All firms want to achieve better financial and reputational performance and the evidence provided by developed economies support the idea that this goal is possible to accomplish. However, the Colombian case involves both companies with large sales volumes that are not the most admired by society, and cases in which highly appreciated and well-ranked companies in terms of corporate reputation are not the most profitable. This research raises several questions that shareholders could take into account, such as:

$R Q 1$. Are companies using financial resources to invest in activities that enhance their reputation but curtail performance in terms of financial indicators?

RQ2. Are top companies with greater market power and good financial results using their dominant position to sustain their economic value creation, instead of reducing the negative perception of the firm?

\section{Limitations and further research}

This research has several limitations that could be overcoming with future research. Further research is needed to advance towards a comprehensive theory explaining the complexity of boards and their characteristics in relationship to firm performance. Such research needs to include features and rules of board members in terms of expertise, training, competences, skills, diversity, independence, enrollment in different boards and other variables assessing organizational diversity. Moreover, it is important to use larger samples to assess the relationship between reputation and FP based on the board's structural characteristics as mediating and moderating variables. Future research using larger data and other countries could test the hypothesis proposed by Zahra and Pearce (1989) which suggests an inverted U-shaped relationship between size and performance using contingency theory to include mediator and moderator variables, i.e. the mediation of corporate social responsibility and its effects on board diversity in the relationship between B-SIZE and corporate performance (Bear et al., 2010).

In summary, this research contributed empirical evidence on the analysis of the relationship between B-SIZE and financial and reputational performance. The results help 
to question normative definitions of best practices in corporate governance, particularly related to emerging economies. Moreover, this research proposed that integrative models that use the framework of contingency theory could be developed further beyond the inclusion of ownership concentration, international activities, and compliance with stock market rules. Variables such as the inclusion of reputation as a corporate performance measure need to be included and more national cases are required in order to build better propositions for theory development.

We expect that this work will motivate and encourage researchers from Latin American countries and other emerging economies to build further knowledge and present local cases to shed more light on the relationship between board features and firm performance, and to promote theoretical discussions, improve practices, and enhance regional codes of corporate governance.

\section{Acknowledgments}

The authors would like to thank the contribution of Andrés Galeano, former student in Business Administration at the School of Management of Externado University, for his valuable data construction. Also, the authors are thankful for the support of Carlos Restrepo, Research Director of the School and the collaboration of Diego Andrés Chavarro $\mathrm{PhD}$ Advisor at Colciencias for his review. Finally, the authors express the gratitude for anonymous reviewers for the useful comments and remark and the Global Innovation and Knowledge Academy (GIKA) for allow us to share this research.

\section{Notes}

1. Network of 57 Chambers of Commerce in Colombia. www.confecamaras.org.co/ (accessed January 15, 2015).

2. www.merco.info/es/countries/6-co (accessed February 20, 2014).

3. http://bpr.securities.com/co/ (accessed February 20, 2014).

4. www.bvc.com.co/pps/tibco/portalbvc/Home/Empresas/Listado+de+Emisores?action=dummy (accessed February 14, 2015).

\section{References}

Barroso, C., Villegas, M.M. and Pérez-Calero, L. (2011), "Board influence on a firm's internationalization”, Corporate Governance: An International Review, Vol. 19 No. 4, pp. 351-367.

Bear, S., Rahman, N. and Post, C. (2010), "The impact of board diversity and gender composition on corporate social responsibility and firm reputation”, Journal of Business Ethics, Vol. 97 No. 2, pp. 207-221.

Belkhir, M. (2009), "Board of director's size and performance in the banking industry", International Journal of Managerial Finance, Vol. 5 No. 2, pp. 201-221.

Bennedsen, M., Kongsted, H.C. and Nielsen, K.M. (2008), "The causal effect of board size in the performance of small and medium-sized firms", Journal of Banking \& Finance, Vol. 32 No. 6 , pp. 1098-1109.

Bonn, I., Yoshikawa, T. and Phan, P.H. (2004), "Effects of board structure on firm performance: a comparison between Japan and Australia”, Asian Business \& Management, Vol. 3 No. 1, pp. 105-125.

Brown, B. and Perry, S. (1994), "Removing the financial performance halo from Fortune's 'Most Admired' companies”, Academy of Management Journal, Vol. 37 No. 5, pp. 1347-1359.

Calabrò, A. and Mussolino, D. (2011), "How do boards of directors contribute to family SME export intensity? The role of formal and informal governance mechanisms", Journal of Management \& Governance, Vol. 17 No. 2, pp. 363-403. 
EJMBE

27,2

Caliskan, E., Icke, B. and Ayturk, Y. (2011), “Corporate reputation and financial performance: evidence from Turkey”, Research Journal of International Studies, Vol. 18, pp. 61-72.

Carney, M. (2005), "Corporate governance and competitive advantage in family-controlled firms", Entrepreneurship Theory and Practice, Vol. 29 No. 3, pp. 249-265.

Casillas, J.C. and Vásquez, A. (2005), “Órganos de Gobierno de la empresa familiar”, in Corona, J. (Ed.), Manual de la Empresa familiar, PricewaterhouseCoopers, Instituto de la Empresa Familiar. Barcelona, Deusto.

Castro, M.S., Brown, C.J. and Báez-Díaz, A. (2009), "Prácticas de gobierno corporativo en América Latina”, Academia. Revista Latinoamericana de Administración, Vol. 43, pp. 26-40.

Chaganti, R.S., Mahajan, V. and Sharma, S. (1985), "Corporate board size, composition and corporate failures in retailing industry”, Journal of Management Studies, Vol. 22 No. 4, pp. 400-417.

Chatterjee, S.D. (2011), "Board composition and performance in Indian firms: a comparative analysis empirical", International Journal of Management Science \& Technology Information, Vol. 1 No. 2 , pp. $1-15$.

Cheng, S. (2008), "Board size and the variability of corporate performance", Journal of Financial Economics, Vol. 87 No. 1, pp. 157-176.

Chepkosgei, P. (2013), "The influence of board of directors composition on financial performance of commercial banks in Kenya", doctoral dissertation, University of Nairobi, Nairobi.

Conyon, M.J. and Peck, S.I. (1998), "Board size and corporate performance: evidence from European countries", The European Journal of Finance, Vol. 4 No. 3, pp. 291-304.

Corbetta, G. and Salvato, C. (2004), “The board of directors in family firms: one size fits all?”, Family Business Review, Vol. 17 No. 2, pp. 119-134.

Dalton, D.R., Daily, C.M., Johnson, J.L. and Ellstrand, A.E. (1999), "Number of directors and financial performance: a meta-analysis", Academy of Management Journal, Vol. 42 No. 6, pp. 674-686.

de Villiers, C., Naiker, V. and van Staden, C.J. (2011), "The effect of board characteristics on firm environmental performance", Journal of Management, Vol. 37 No. 6, pp. 1636-1663.

Deephouse, D.L. (1997), "The effect of financial and media reputations on performance", Corporate Reputation Review, Vol. 1 Nos 1/2, pp. 68-71.

Delgado-García, J.B., Quevedo, E. and Fuente, D. (2010), "The impact of ownership structure on corporate reputation: evidence from Spain”, Corporate Governance: An International Review, Vol. 18 No. 6, pp. 540-556.

Dunbar, R.L. and Schwalbach, J. (2000), "Corporate reputation and performance in Germany", Corporate Reputation Review, Vol. 3 No. 2, pp. 115-123.

Eberl, M. and Schwaiger, M. (2005), "Corporate reputation: disentangling the effects on financial performance", European Journal of Marketing, Vol. 39 Nos 7/8, pp. 838-854.

Ehikioya, B.I. (2009), "Corporate governance structure and firm performance in developing economies: evidence from Nigeria”, Corporate Governance, Vol. 9 No. 3, pp. 231-243.

Eisenberg, T., Sundgren, S. and Wells, M.T. (1998), "Larger board size and decreasing firm value in small firms", Journal of Financial Economics, Vol. 48 No. 1, pp. 35-54.

Fernández, L.V., Jara-Bertin, M. and Pineaur, F.V. (2015), "Social responsibility practices, corporate reputation and financial performance", Revista de Administração de Empresas, Vol. 55 No. 3, pp. 329-344.

Flanagan, D.J., O'Shaughnessy, K.C. and Palmer, T.B. (2011), "Re-assessing the relationship between the Fortune reputation data and financial performance: overwhelming influence or just a part of the puzzle?”, Corporate Reputation Review, Vol. 14 No. 1, pp. 3-14.

Fombrun, C. and Shanley, M. (1990), "What's in a name? Reputation building and corporate strategy", Academy of Management Journal, Vol. 33 No. 1, pp. 233-258.

Fombrun, C.J. (1996), Reputation: Realizing Value from the Corporate Image, Harvard Business Press, Boston, MA. 
Fuente, J.M. and Quevedo, E. (2003), "Empirical analysis of the relationship between corporate reputation and financial performance: a survey of the literature", Corporate Reputation Review, Vol. 6 No. 2, pp. 161-177.

Gabbioneta, C., Ravasi, D. and Mazzola, P. (2007), "Exploring the drivers of corporate reputation: a study of Italian securities analysts", Corporate Reputation Review, Vol. 10 No. 2, pp. 99-123.

Garay, U., González, G., González, M. and Hernández, Y. (2006), "Índice de buen gobierno corporativo y desempeño financiero en la Bolsa de Valores de Caracas", Estudio IESA, No. 24, pp. 1-22.

Glaewketgarn, T. (2013), "Corporate governance and firm performance of family ownership, control and management firms in Thailand", Journal of International Finance Studies, Vol. 13 No. 2, pp. 5-38.

Gómez-Betancourt, G., Vergara, M.P.L., Ramírez, J.B.B. and Payán, J.O.M. (2012), "Estudio sobre el desempeño de las empresas familiares colombianas que cotizan en la bolsa de valores, frente a las empresas no familiares", Entramado, Vol. 8 No. 1, pp. 28-42.

Guest, P.M. (2009), "The impact of board size on firm performance: evidence from the UK", The European Journal of Finance, Vol. 15 No. 4, pp. 385-404.

Hammond, S.A. and Slocum, J.W. (1996), "The impact of prior firm financial performance on subsequent corporate reputation”, Journal of Business Ethics, Vol. 15 No. 2, pp. 159-165.

Harris, M. and Raviv, A. (2006), "A theory of board control and size", The Review of Financial Studies, Vol. 21 No. 4, pp. 1797-1832.

Herrera-Echeverri, H., Geleilate, J.G., Gaitan-Riaño, S., Haar, J. and Soto-Echeverry, N. (2015), "Export behavior and board independence in Colombian family firms: the reverse causality relationship", Journal of Business Research, Vol. 69 No. 6, pp. 2018-2029.

Hillman, A.J. and Dalziel, T. (2003), "Boards of directors and firm performance: integrating agency and resource dependence perspectives", Academy of Management Review, Vol. 28 No. 3, pp. 383-396.

Hillman, A.J., Cannella, A.A. and Paetzold, R.L. (2000), "The resource dependence role of corporate directors: Strategic adaptation of board composition in response to environmental change", Journal of Management Studies, Vol. 37 No. 2, pp. 235-256.

Inglis, R., Morley, C. and Sammut, P. (2006), "Corporate reputation and organisational performance: an Australian study”, Managerial Auditing Journal, Vol. 21 No. 9, pp. 934-947.

Iwu-Egwuonwu, R.C. (2011), “Corporate reputation \& firm performance: empirical literature evidence”, International Journal of Business and Management, Vol. 6 No. 4, pp. 197-206.

Jackling, B. and Johl, S. (2009), "Board structure and firm performance: evidence from India's top companies”, Corporate Governance: An International Review, Vol. 17 No. 4, pp. 492-509.

Jensen, M. (1993), "The modern industrial revolution, exit, and the failure of internal control systems", The Journal of Finance, Vol. 48 No. 3, pp. 831-880.

Jensen, M.C. and Meckling, W.H. (1979), "Theory of the firm: managerial behavior, agency costs, and ownership structure", Journal of Financial Economics, Vol. 3 No. 4, pp. 305-360.

Kao, H.S. and Kao, C.P. (2013), "The relationship between board characteristics, social welfare and operational performance in the non-profit hospitals", Journal of Strategic and International Studies, Vol. 8 No. 3, pp. 70-84.

Kumar, N. and Singh, J.P. (2013), "Effect of board size and promoter ownership on firm value: some empirical findings from India", Corporate Governance: The International Journal of Business in Society, Vol. 13 No. 1, pp. 88-98.

Lee, J. and Jungbae Roh, J. (2012), "Revisiting corporate reputation and firm performance link", Benchmarking: An International Journal, Vol. 19 Nos 4/5, pp. 649-664.

Lefort, F. and Urzúa, F. (2008), "Board independence, firm performance and ownership concentration: evidence from Chile", Journal of Business Research, Vol. 61 No. 6, pp. 615-622.

Lehn, K.M., Patro, S. and Zhao, M. (2009), "Determinants of the size and composition of US corporate boards: 1935-2000”, Financial Management, Vol. 38 No. 4, pp. 747-780. 
EJMBE

27,2

Liang, Q., Xu, P. and Jiraporn, P. (2013), "Board characteristics and Chinese bank performance", Journal of Banking \& Finance, Vol. 37 No. 8, pp. 2953-2968.

Mak, Y.T. and Kusnadi, Y. (2005), "Size really matters: further evidence on the negative relationship between board size and firm value", Pacific-Basin Finance Journal, Vol. 13 No. 3, pp. 301-318.

Mizruchi, M.S. (2004), "Berle and means revisited: the governance and power of large US corporations", Theory and Society, Vol. 33 No. 5, pp. 579-617.

Musteen, M., Datta, D.K. and Kemmerer, B. (2010), "Corporate reputation: do board characteristics matter?”, British Journal of Management, Vol. 21 No. 2, pp. 498-510.

Neubauer, F. and Lamk, A. (1998), The Family Business: Its Governance for Sustainability, Macmillan Press, London.

Neville, B.A., Bell, S.J. and Mengüç, B. (2005), "Corporate reputation, stakeholders and the social performance-financial performance relationship”, European Journal of Marketing, Vol. 39 Nos 9/10, pp. 1184-1198.

Palaniappan, G. (2017), "Determinants of corporate financial performance relating to board characteristics of corporate governance in Indian manufacturing industry: an empirical study”, European Journal of Management and Business Economics, Vol. 26 No. 1, pp. 67-85.

Pfeffer, J. (1972), "Size and composition of corporate boards of directors: the organization and its environment", Administrative Science Quarterly, Vol. 17 No. 2, pp. 218-228.

Pfeffer, J. and Salancik, G.R. (1978), The External Control of Organizations: A Resource Dependence Perspective, Harper \& Row, New York, NY.

Platt, H. and Platt, M. (2012), "Corporate board attributes and bankruptcy", Journal of Business Research, Vol. 65 No. 8, pp. 1139-1143.

Quevedo, E., Fuente, J.M. and García, J.B.D. (2005), "Reputación corporativa y creación de valor. Marco teórico de una relación circular", Investigaciones europeas de dirección y economía de la empresa, Vol. 11 No. 2, pp. 81-97.

Raheja, C.G. (2005), "Determinants of board size and composition: a theory of corporate boards", Journal of Financial and Quantitative Analysis, Vol. 40 No. 2, pp. 283-306.

Revista Dinero (2013), "El buen nombre”, Revista Dinero, No. 426, July 26 de 2013.

Rivera, H.A. (2012), "Perdurabilidad empresarial: concepto, estudios, hallazgos", Cuadernos de Administración, Vol. 28 No. 47, pp. 104-113.

Roberts, P.W. and Dowling, G.R. (2002), "Corporate reputation and sustained superior financial performance”, Strategic Management Journal, Vol. 23 No. 12, pp. 1077-1093.

Rose, C. and Thomsen, S. (2004), "The impact of corporate reputation on performance: some danish evidence”, European Management Journal, Vol. 22 No. 2, pp. 201-210.

Said, A.A., HassabElnaby, H.R. and Wier, B. (2003), "An empirical investigation of the performance consequences of nonfinancial measures", Journal of Management Accounting Research, Vol. 15 No. 1, pp. 193-223.

Sarpal, S. and Singh, F. (2013), "Board size and corporate performance: an empirical investigation", International Journal of Business Ethics in Developing Economies, Vol. 2 No. 1, pp. 1-8.

Schwaiger, M. (2004), "Components and parameters of corporate reputation. an empirical study", Schmalenbach Business Review, Vol. 56 No. 1, pp. 46-71.

Shukeri, S.N., Shin, O.W. and Shaari, M.S. (2012), "Does board of director's characteristics affect firm performance? Evidence from Malaysian public listed companies”, International Business Research, Vol. 5 No. 9, pp. 120-127.

Skouloudis, A., Evangelinos, K. and Kourmousis, F. (2010), "Assessing non-financial reports according to the global reporting initiative guidelines: evidence from Greece", Journal of Cleaner Production, Vol. 18 No. 5, pp. 426-438. 
Tonello, M. (2010), "Board composition and organization issues", in Baker, K. and Anderson, R. (Eds), Corporate Governance: A Synthesis of Theory, Research, and Practice, Kolb Series in Finance, John Wiley \& Songs, Inc., Hoboken, NJ.

Uadiale, O.M. (2010), "The impact of board structure on corporate financial performance in Nigeria", International Journal of Business \& Management, Vol. 5 No. 10, pp. 155-166.

Ugwoke, R.O., Onyeanu, E.O. and Modebe, N.J. (2013), "Board size and composition and corporate performance: the case of non-financial companies on the Nigerian stock exchange", European Journal of Business and Management, Vol. 5 No. 26, pp. 177-185.

Walsh, G. and Wiedmann, K.P. (2004), "A conceptualization of corporate reputation in Germany: an evaluation and extension of the RQ", Corporate Reputation Review, Vol. 6 No. 4, pp. 304-312.

Xie, J. and Fukumoto, Y. (2013), “A new finding for corporate board size effects: evidence from Japan”, The Singapore Economic Review, Vol. 58 No. 4, pp. 1-12.

Yammeesri, J. and Herath, S.K. (2010), "Board characteristics and corporate value: evidence from Thailand", Corporate Governance, Vol. 10 No. 3, pp. 279-292.

Yasser, Q.R., Mamun, A.A. and Rodrigs, M. (2017), "Impact of board structure on firm performance: evidence from an emerging economy", Journal of Asia Business Studies, Vol. 11 No. 2, pp. 210-228.

Yermack, D. (1996), "Higher market valuation of companies with a small board of directors", Journal of Financial Economics, Vol. 40 No. 2, pp. 185-211.

Zahra, S.A. and Pearce, J.A. (1989), "Boards of directors and corporate financial performance: a review and integrative model", Journal of Management, Vol. 15 No. 2, pp. 291-334.

Zhang, R. and Rezaee, Z. (2009), "Do credible firms perform better in emerging markets? evidence from China", Journal of Business Ethics, Vol. 90 No. 2, pp. 221-237.

\section{Corresponding author}

Luis Antonio Orozco can be contacted at: luis.orozco@uexternado.edu.co

For instructions on how to order reprints of this article, please visit our website: 